\title{
Kaurna in Tasmania: A case of mistaken identity
}

\author{
Rob Amery
}

Until now, a list of some eighty words has been considered to be part of the corpus of material on the languages of Tasmania. Plomley, the most comprehensive source on the documentation of the languages of Tasmania, ${ }^{1}$ attributes these Kaurna words, compiled by Charles Robinson, the son of George Augustus Robinson, to the Ben Lomond area of north-east Tasmania. ${ }^{2}$

In this paper I will demonstrate that these eighty words are irrefutably Kaurna, the language of Adelaide and the Adelaide Plains of South Australia. Further, I will put forward a probable explanation as to how these words came to be included within the Robinson papers. Further I will identify the Kaurna woman who was the probable source.

\section{Kaurna words first noticed within Tasmanian materials}

Early in 1993, I first noticed the Kaurna word kauwe 'water' written as cow.we when flicking through Plomley's 1976 A Word-list of the Tasmanian Aboriginal Languages. Over several decades of painstaking work, Plomley has collated almost all of the words ever recorded on the languages of Tasmania. Plomley compiled his wordlist from the records of at least thirty different observers, gathering together all the words from the various sources and listing them under an English headword. So under the word for 'water' for instance, Plomley lists words recorded by these different observers and has taken care to specify the source, location and informant, where such information is available.

Cow.we seemed out of place amongst the other words recorded for water. It was shorter than most of the other Tasmanian words which are often polysyllabic. Variants of other terms for water were given by a number of observers, whereas cow.we stood out on its own. Interestingly, other words lar.cun.er and la.un.er for water which are cognate with other Tasmanian languages are provided also for the Ben Lomond language. No other Tasmanian words for water were remotely similar to cow.we. I didn't think much of it at the time. At that stage I suspected that it might have been a Kaurna word that

\footnotetext{
' Plomley 1976.

${ }^{2}$ This list of Kaurna words is insignificant in number relative to the total corpus of Tasmanian materials. Plomley (1976) lists some 1400 English head words. Under each of these head words are numerous alternative terms and minor variations of spelling as recorded by the different observers of the various Tasmanian languages.
} 
Figure $1 \quad$ Kaurna wordlist from Plomley (1976:459-61)

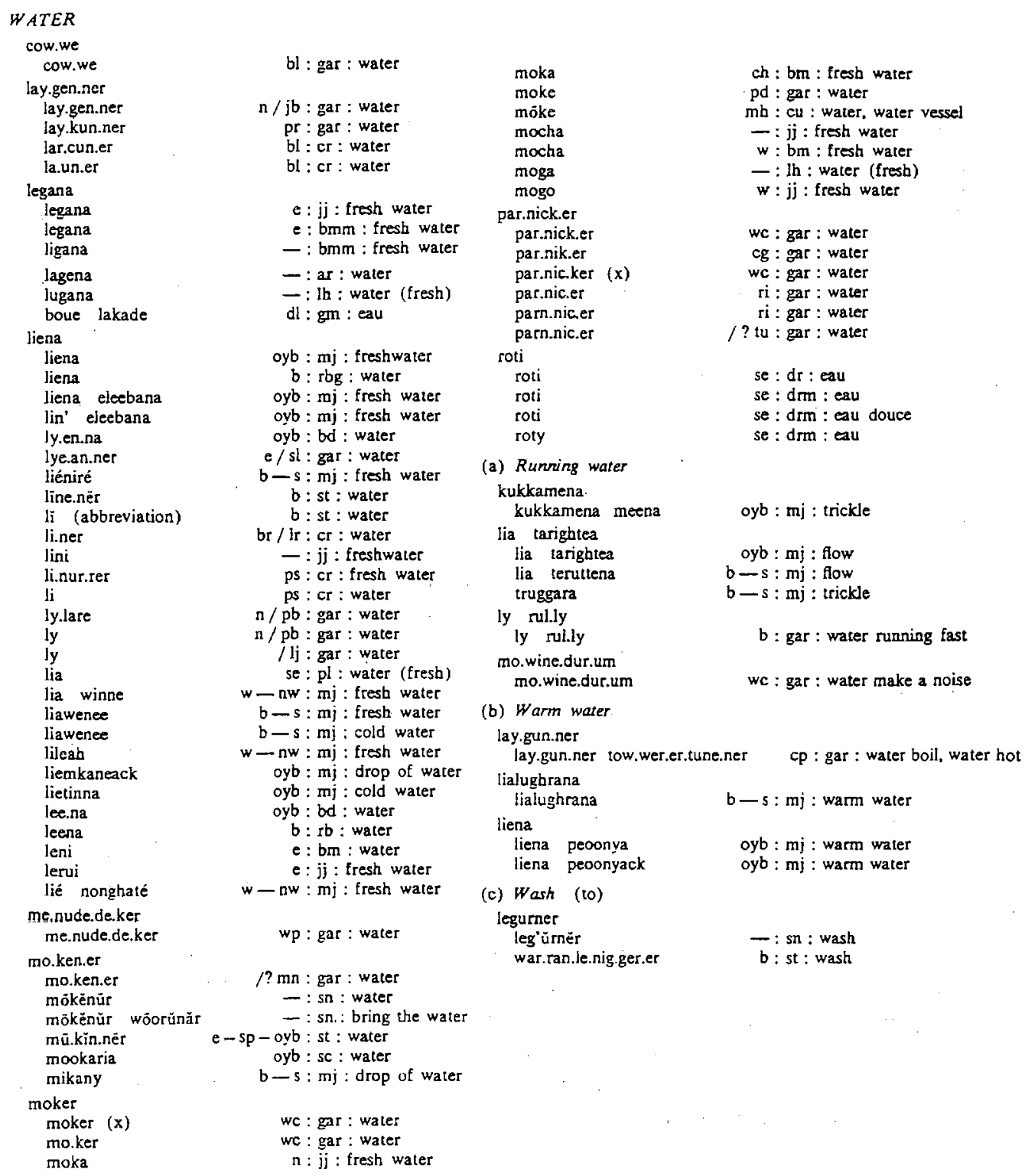


had been introduced to Tasmania by Tasmanian women or sealers who had associated with Kaurna women on Kangaroo Island.

During the course of 1994, again I had cause to work from Plomley. I noticed that a number of other words collated by Plomley were similar in form and meaning to Kaurna words. Words like you.co 'whaleboat', wal.le 'house', me.you 'man' and tin.to 'sun' quickly came to my attention. None of these words bore any relationship to other Tasmanian words either. So I began to make a more methodical search, page by page. I soon realised that all the Kaurna words were said to come from the same region, Ben Lomond, in north eastern Tasmania, with the recording attributed to either Charles Robinson or George Augustus Robinson. I found that I was often able to predict which word within a given list was a Kaurna word, irrespective of whether I was familiar with that particular Kaurna word or not.

Some of these words stood out from the corpus of Tasmanian words in other respects too. A number began with the letter $i$, yet Tasmanian words beginning with $i$ are exceedingly rare. They are as follows:

\begin{tabular}{|c|c|c|c|}
\hline \multirow{4}{*}{$\begin{array}{l}\text { Robinson's Kaurna } \\
\text { i.tho } \\
\text { i.tho } \\
\text { i.char.ne }\end{array}$} & \multicolumn{3}{|c|}{$\begin{array}{l}\text { Kaurna, according to } \\
\text { Teichelmann \& Schürmann }(1840)^{3}\end{array}$} \\
\hline & 'give' & ngaityo & 'mine $e^{\prime 4}$ \\
\hline & 'me' & ngaityo & 'mine' \\
\hline & $\begin{array}{l}\text { 'tired' } \\
\text { feeble; tired' }\end{array}$ & ngaityanna & 'weak; faint; \\
\hline i.char.le & 'father' & ngaityerii & 'my father' \\
\hline i.chie & 'mother' & ngaityaii & 'my mother' \\
\hline i.chu.ung.er & 'brother' & ngaityo yunga & 'my brother' \\
\hline i.chi.yuck.er.nu & 'sister' & ngaityo yakkana & 'my sister' \\
\hline i.thoe ar mi.ther & 'my wife' & ngaityo ngammaitya & 'my woman' \\
\hline i.thoemoker.un der.re & 'forget' & ngaityo mukandari & '[1] forgot mine' \\
\hline
\end{tabular}

The term given for 'forget' is absolutely convincing because it consists of several meaningful parts in Kaurna. The relationship terms too are complex and involve the word ngaityo 'my' used in combination with another word. For instance, Robinson's i.charle 'father' is equivalent to the Kaurna word ngaityerli which is glossed by Teichelmann \& Schürmann (1840) as 'my father; contraction of ngaityo yerli [ngaityo 'my' yerli 'father']'. Further, nin.co.ar.mi.ther 'your wife' = ninko ngammaitya 'your woman' contrasts with i.thoe.ar.mi.ther = ngaityo ngammaitya 'my woman' above, thus adding further weight to the argument.

\footnotetext{
${ }^{3}$ Teichelmann \& Schürmann (1840), which includes approximately 2,000 vocabulary entries, and Teichelmann (1857) are the most comprehensive and reliable sources on the Kaurna language. A comparison with modern recordings in neighbouring related languages (eg Nukunu) indicates that they represented most but not all sounds in the Kaurna language and were reasonably consistent in their spellings. Accordingly, Teichelmann \& Schürmann (1840), henceforth abbreviated to T\&S (1840), is used as the point of reference for comparison with Robinson's wordlist.

'It is easy to imagine how confusion between 'give' and 'mine' might arise. Robinson might have been gesturing with a motion of the arm towards himself in trying to elicit the word for 'give' whilst this might have been misinterpreted by Kalloongoo as 'mine'.
} 
Furthermore, a great many Tasmanian words commence with 1 and r. However, Kaurna words never begin with 1 and r. As I had observed with cow.we many of the other Kaurna words were also short two syllable words. Tasmanian words are more often three syllables or longer, though two syllable words are certainly present.

Most importantly however, the Kaurna words usually bore no relationship whatsoever to the other Tasmanian words recorded for that particular item. Plomley lists 56 of the 80 words separately. Where he has associated the Kaurna word with other Tasmanian words, the resemblance is usually not close. For instance, Plomley has associated Kaurna wung.car.ne 'speak' (T \& S wanggandi) with Oyster Bay munkannára 'eloquent'. These words are not especially close in either form or meaning. Kaurna yar.ter 'country' is listed with troun.ter, trout.ter and troune, presumably on the basis of the end of the word. This is one of the few cases where the Kaurna word is grouped together with a Ben Lomond word. So yar.ter and troune 'country' have been regarded as variants of the same word in the same language by Plomley, yet there is nothing in common between the two forms. All the vowels and the consonants are different.

The Kaurna word wilto 'hawk' (T\&S, 1840) is perhaps the closest in form and meaning to Plomley's groupings which involve a Kaurna word recorded by Robinson:

$\begin{array}{lll}\text { wil.er.de } & \mathrm{b}: \text { gar } & \text { 'hawk' } \\ \text { weelaty } & \mathrm{b}-\mathrm{s}: \mathrm{mj} & \text { 'eagle' } \\ \text { will.to } & \mathrm{bl}: \mathrm{cr} & \text { 'hawk' }\end{array}$

( $b$ = Bruny Island; gar = George Augustus Robinson; $b-s=$ Bruny Island - southern tribes; $\mathrm{mj}=$ Joseph Milligan; bl = Ben Lomond; $\mathrm{cr}=$ Charles Robinson; $\mathrm{T} \& \mathrm{~S}=$ Teichelmann \& Schürmann, 1840)

The first two are clearly variants of the same word written with different English conventions representing a word something like [wilati] when written phonetically. Linking will.to [wiltu] with these two words however involves the introduction of a vowel in between the $\mathrm{l}$ and $\mathrm{t}$ and a vowel change $\mathrm{u} \rightarrow \mathrm{i}$. The resemblance is not particularly close.

After making these observations of Plomley (1976), I suspected that the Kaurna words constituted a separate wordlist, so I pursued the original handwritten wordlists held in the Mitchell library in Sydney. I found that the Kaurna words did indeed constitute a separate wordlist (Figures 2,3,4). Below, the Kaurna words transcribed by Robinson are listed according to the order in which they appear in Plomley 1976. Plomley has ordered his wordlists alphabetically according to his English headword. 
28

ABORIGINAL HISTORY 199620

Figure 2

Handwritten Kaurna wordlists (Courtesy of the Mitchell Library, Sydney)

Schar ne - thed

thremaker in der re - To target

Har car re . . . lod

Lar to yar to _...baby

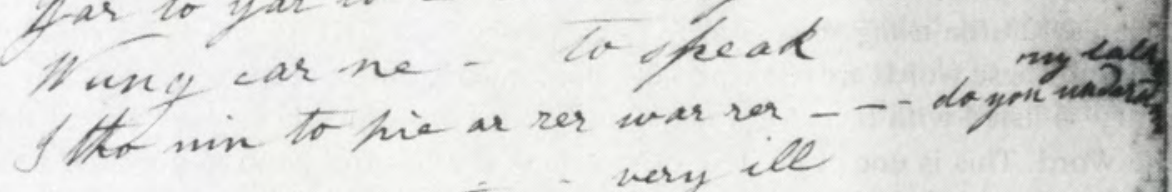

Un dar ne -

very ill

Ene mer -

Hill. to Trom

Yucito to frap

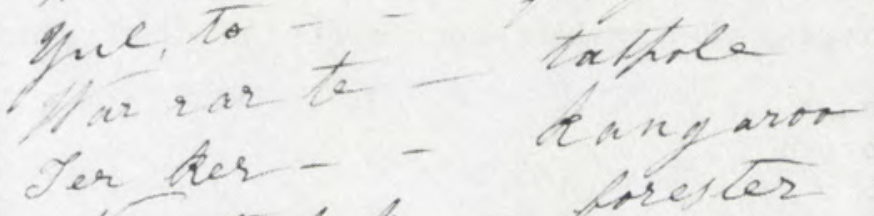

inx to buke prester

ing ec dac ditto-

toufolear saltweter

Pil tar - . Kosoum

Noker. mo ker... Kangaror rat

tarrer _. Bandacula

Howy go - ming tack

Whitar me - to rime

Hntlar unter - Juland

Ha mer tor Anle

Ham mer -

\& Llan

butter -. Achrob

You ro ren see - to innt

Hin cofparl ter re.. dead

Younis whale brat

wll you nes - - black

Pim dim une yor - whte man.

therer car ne 
Figure 3 Handwritten Kaurna wordlists (Courtesy of the Mitchell Library, Sydney)

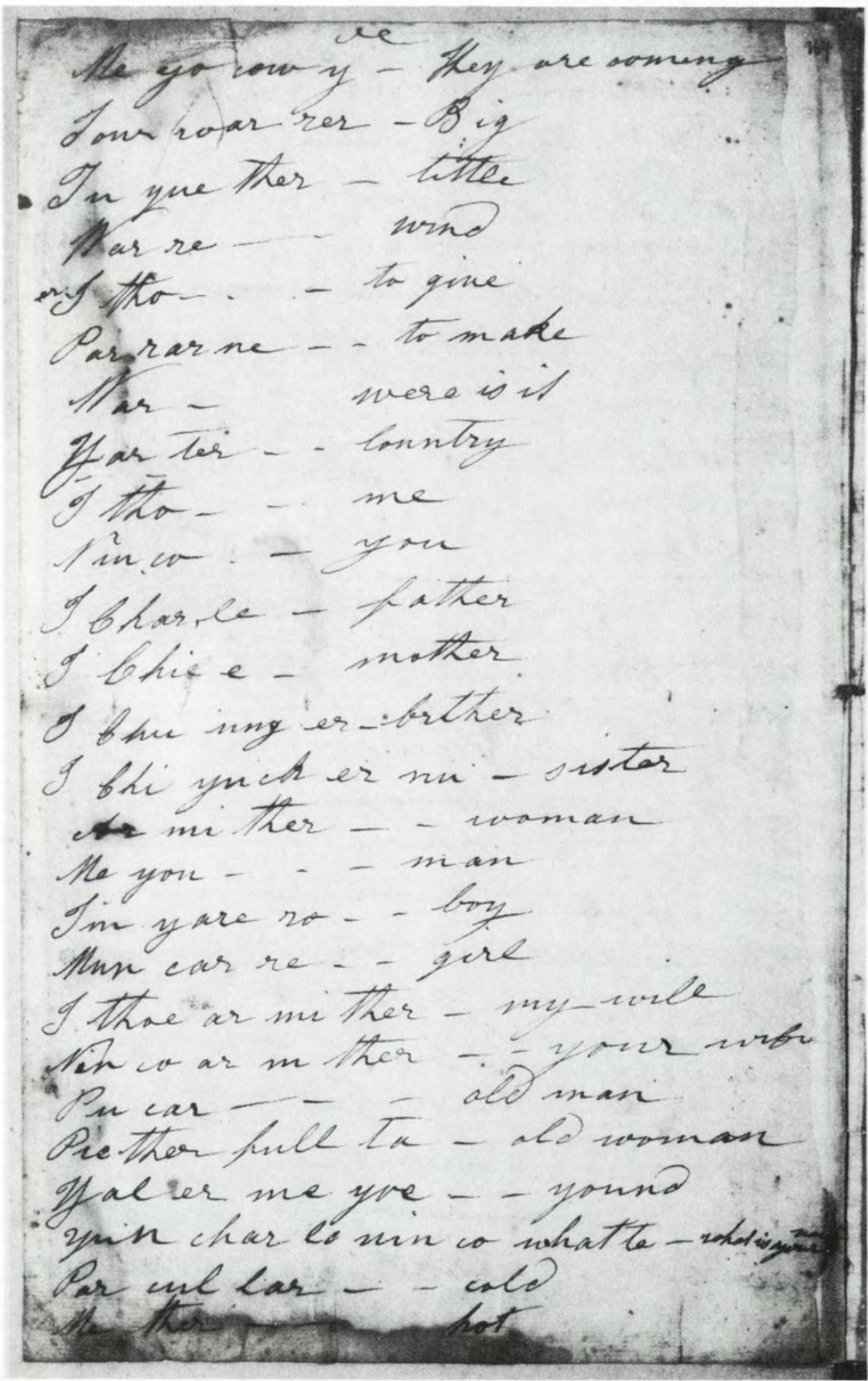


Figure 4 Handwritten Kaurna wordlists (Courtesy of the Mitchell Library, Sydney)

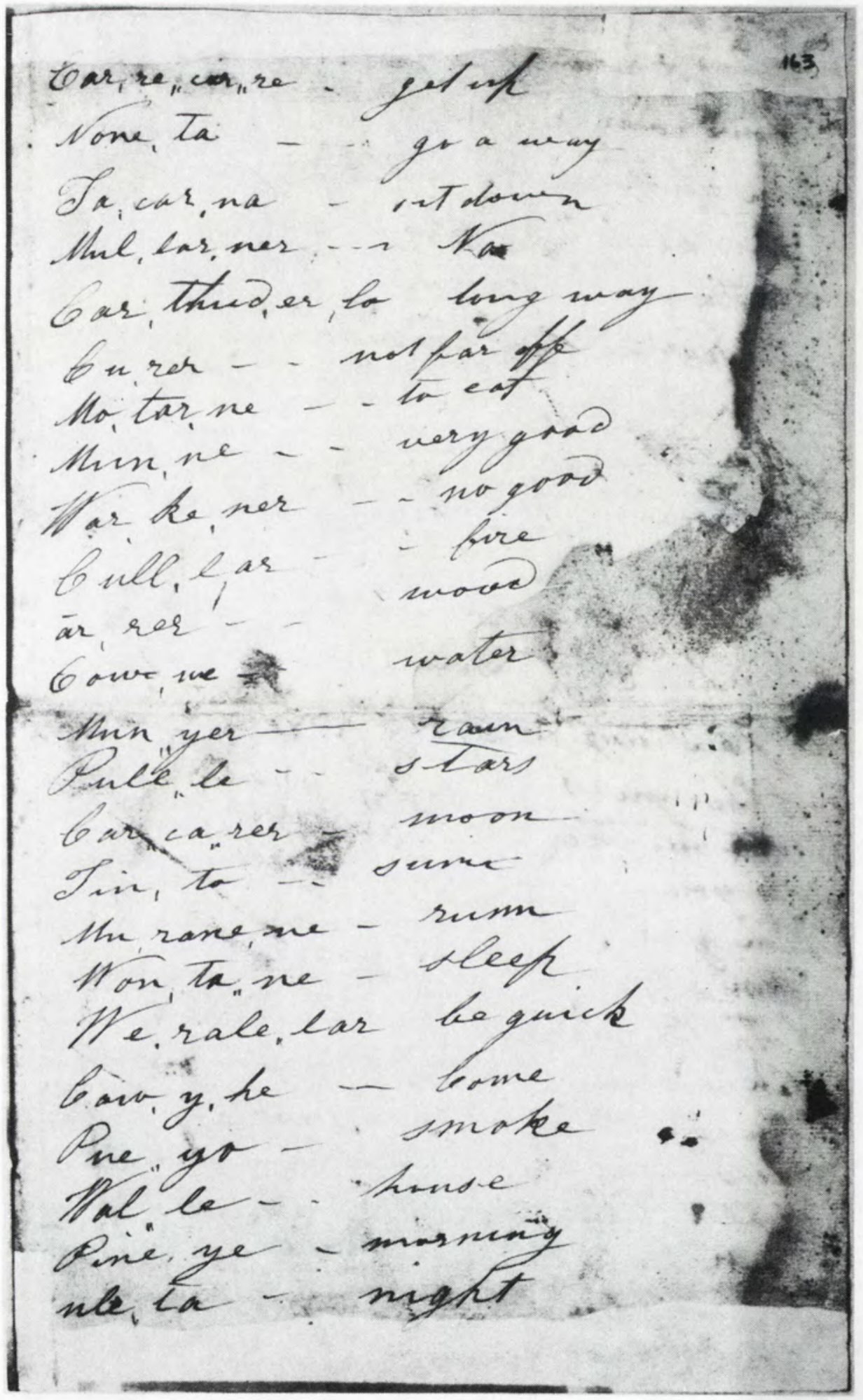


The nearest identifiable counterpart or related words from Teichelmann \& Schürmann (1840) are listed alongside each of Robinson's Kaurna words:

Robinson's Kaurna Wordlist as compiled by Plomley (1976)

(bl = Ben Lomond; $\mathrm{cr}=$ Charles Robinson; gar = George Augustus Robinson)

$\begin{array}{ll}\text { Robinson's 'Ben } & \text { Lomond' } \\ \text { yar.to.yar.to } & \text { 'baby' } \\ \text { war.ke.ner } & \text { 'no good' } \\ \text { will.to } & \text { 'hawk' } \\ \text { pull.you.ner } & \text { 'black' } \\ \text { you.co } & \text { 'whaleboat' } \\ \text { tin.yare.ro } & \text { 'boy' } \\ \text { cu.rer } & \text { 'not far off' } \\ \text { par.cul.lar } & \text { 'cold' } \\ \text { caw.y.he } & \text { 'come' } \\ \text { me.yo.cow.y } & \text { 'they are coming' } \\ \text { yar.ter } & \text { 'country' } \\ \text { mu.rer.car.ne } & \text { 'cry' } \\ \text { win.co.parl.der.re 'dead' } & \end{array}$

$\begin{array}{ll}\text { car.thud.er.lo } & \text { 'long way' } \\ \text { mo.tar.ne } & \text { 'eat' } \\ \text { i.char.le } & \text { 'father' } \\ \text { i.chie } & \text { 'mother' } \\ \begin{array}{l}\text { i.chu.ung.er } \\ \text { i.chi.yuck.er.nu }\end{array} & \text { 'brother' } \\ \text { cull.ar } & \text { 'fire' } \\ \text { i.thoe.moker. } & \\ \text { un.der.re } & \text { 'forget' }\end{array}$

$\begin{array}{ll}\text { mun.car.re } & \text { 'girl' } \\ \text { i.tho } & \text { 'give' } \\ \text { none.ta } & \text { 'go, go away' } \\ \text { munni } & \text { 'good' } \\ \text { mo.in.ter } & \text { 'hill' }\end{array}$

\section{Kaurna (T\&S, 1840)}

\begin{tabular}{|c|c|c|}
\hline bl: $\mathrm{cr}$ & yerthondi & 'to grow' \\
\hline bl: $\mathrm{cr}$ & wakkinna & 'bad, wicked' \\
\hline ol: $\mathrm{cr}$ & wilto & 'species of eagle' \\
\hline bl: $\mathrm{cr}$ & pulyonna & 'black' \\
\hline bl: gar & yoko & 'ship' \\
\hline bl: gar & tinyara & 'boy, lad, youth' \\
\hline bl: $\mathrm{cr}$ & kura & 'near, not far off' \\
\hline bl: $\mathrm{cr}$ & bakkadla & 'hoar frost' \\
\hline bl: cr & kawai & 'come' \\
\hline 1: $\mathrm{cr}$ & meyu kawai & 'men coming' \\
\hline bl: $\mathrm{cr}$ & yerta & 'earth, land, country' \\
\hline bl: $\mathrm{cr}$ & murkandi & 'to cry, weep, lament' \\
\hline \multirow[t]{3}{*}{ bl: $\mathrm{cr}$} & \multicolumn{2}{|c|}{ wingko paltari $=$ breath beaten out } \\
\hline & wingko & 'lungs; breath' \\
\hline & paltandi & $\begin{array}{l}\text { 'knock; push; throw; } \\
\text { beat; pluck off; pull out' }\end{array}$ \\
\hline bl: $\mathrm{cr}$ & karradlo & 'far off; long away' \\
\hline$: \mathrm{cr}$ & mutandi & 'to eat' \\
\hline $\mathrm{bl}: \mathrm{cr}$ & ngaityerli & 'my father' \\
\hline $\mathrm{bl}: \mathrm{cr}$ & ngaityaii & 'my mother' \\
\hline bl: cr & ngaityo yunga & 'my brother' \\
\hline $\mathrm{bl}: \mathrm{cr}$ & ngaityo yakkana & 'my sister' \\
\hline bl: $\mathrm{cr}$ & gadla & 'fire, fuel, wood' \\
\hline \multirow[t]{3}{*}{ bl: cr } & \multicolumn{2}{|c|}{ ngaityo mukandari $=$ forgot mine } \\
\hline & ngaityo & 'mine' \\
\hline & mukandariappendi & 'to forget; leave behind' \\
\hline bl: gar & mankarra & 'girl; young female' \\
\hline & ngaityo & 'mine' \\
\hline $\mathrm{bl}: \mathrm{cr}$ & nurnti & 'further; off; away' \\
\hline bl: cr & marni & 'fat; rich; good' \\
\hline ble cr & mukurta & 'mountain' \\
\hline
\end{tabular}

(this word was mis-transcribed by Plomley - should be mo.cu.ter - see original)

\begin{tabular}{|c|c|c|c|c|}
\hline zer & 'hot' & bl: $\mathrm{cr}$ & meda & 'heat, flame; hot etc' \\
\hline walle & 'house' & $\mathrm{bl}: \mathrm{cr}$ & wodli & 'hut; house' \\
\hline you.ro.rin.ne & 'hunt' & $\mathrm{bl}: \mathrm{cr}$ & yurrurendi & 'to creep, sneak, steal upon' \\
\hline
\end{tabular}

\footnotetext{
${ }^{5}$ Some of Teichelmann \& Schürmann's glosses have been reduced or abbreviated for the sake of clarity.
} 


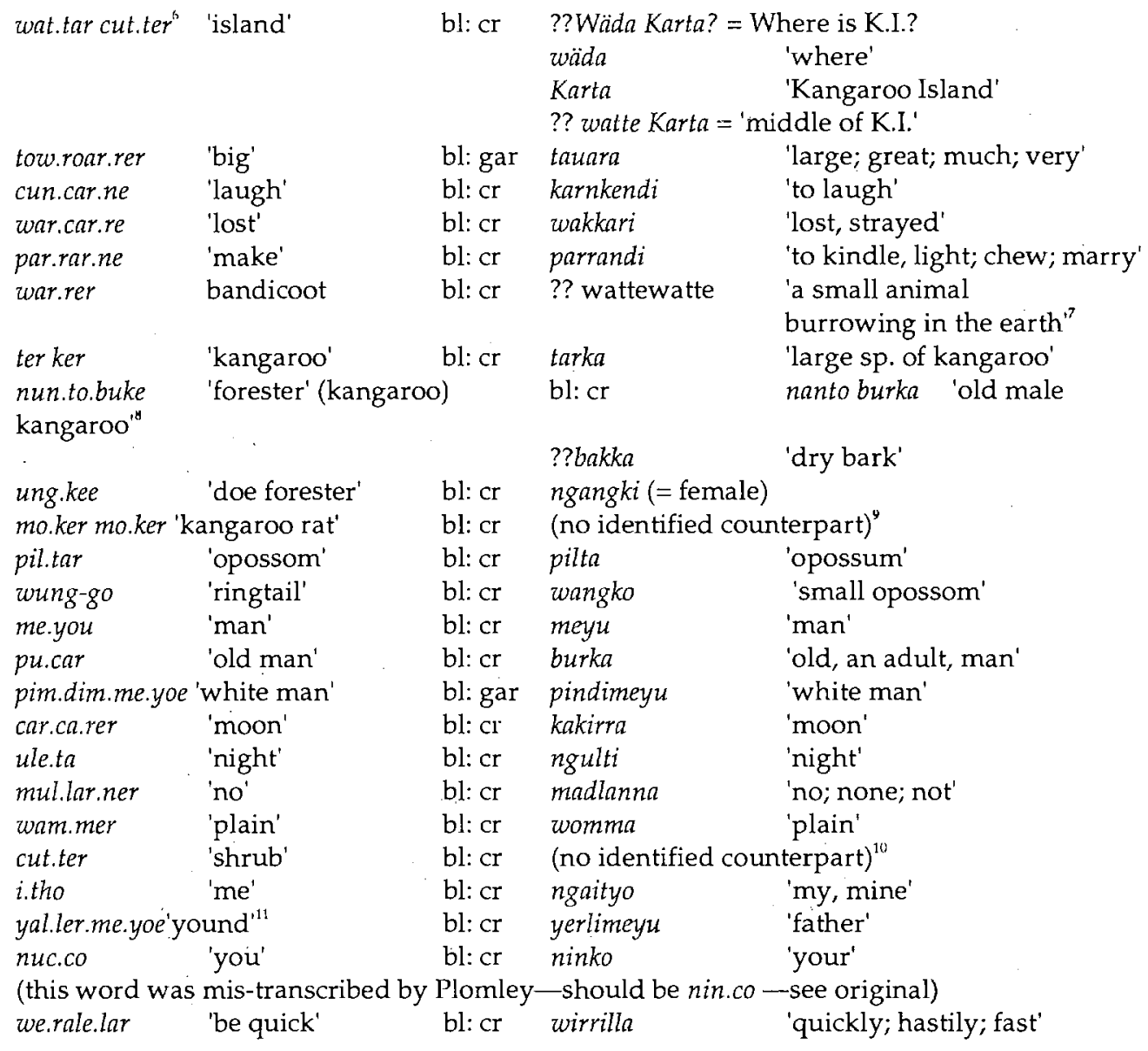

\footnotetext{
${ }^{6}$ Wat.tar cut.ter 'island' bears some similarity to Gaimard's (1833) wategakal 'island' and a striking resemblance to the Raminjeri word wãteakattauwe 'small rocky island' (Meyer, 1843: 106), though Meyer records another word Kukakungar for 'Kangaroo Island'. -auwe is a productive suffix in Ramindjeri meaning 'belonging to'. Kaurna has watte 'middle; midst' and wattingga 'between', so perhaps wat.tar cut.ter means 'in the middle of Kangaroo Island'. However, as we shall see, George Augustus Robinson records an almost identical form wat.ter.ker.ter which he also glosses as 'an island'. The etymology of this word is inconclusive.

${ }^{7}$ Whilst Teichelmann \& Schürmann's wattewatte is perhaps not too close to Robinson's war.rer, similar words have been recorded in neighbouring languages. Note wara 'rat' in Narrunga and warda 'rat' in Ngadjuri.

'Wyatt lists nanto boorka 'an old hoary male kangaroo'.

'There is some resemblance to Ngarrindjeri mikurri 'bandicoot (spotted)' (Taplin, 1879: 126) and to the word murucurlu recorded on the inside cover of Sturt's Journal 13/9-30/9/1845 as 'Native name of animil <sic > got from the Natives on the Park land 20th Augt 1845' (noted by David Nash). These resemblances remain inconclusive.

"Whilst no similar term was recorded by Teichelmann \& Schürmann (1840) similar words have been recorded by other observers of Kaurna. Note cur-tah 'scrub, bush, underwood' (Piesse, 1840) and kerta 'a forest' (Wyatt).

"Yound' is an English dialectal variation of 'yond' or 'yonder' which would translate as nguntya. Presumably the glossing of this word as 'yound' was the result of a misunderstanding on Robinson's part. Yal.ler.me.yoe definitely looks like a compound where meyu 'man; person' is the second element.
} 


\begin{tabular}{|c|c|c|c|c|}
\hline mun.yer & 'rain' & bl: $\mathrm{cr}$ & manya & 'cold; rainy' \\
\hline car.re.car.re & 'get up' & bl: $\mathrm{cr}$ & karri karri & 'stand up!' \\
\hline mu.rane.ne & 'run' & bl: $\mathrm{cr}$ & murrendi & 'to go; walk; travel' \\
\hline clu.po.lar & 'salt water' & bl: cr & kopurlo & 'sea water' \\
\hline \multicolumn{5}{|c|}{ (this word was mis-transcribed by Plomley-should be cu.pollar - see original) } \\
\hline un.dar.ne & 'very ill' & bl: cr & ngandandi & 'to be ill; sick; feel pain' \\
\hline muck.car.ne & 'sing' & $\mathrm{bl}: \mathrm{cr}$ & makkandi & $\begin{array}{l}\text { 'to shake, quiver in the } \\
\text { legs as in dancing' }\end{array}$ \\
\hline ta.car.na & 'sit down' & bl: cr & tikkarna! & 'sit down!' (you plural) \\
\hline wonta.ne & 'sleep' & bl: cr & $\begin{array}{l}\text { wandendi } \\
\text { medo wandendi }\end{array}$ & $\begin{array}{l}\text { 'to lie down' } \\
\text { 'to lie down to sleep' }\end{array}$ \\
\hline tu.yu.ther & 'little' & bl: cr & tukkutya & 'small; little' \\
\hline pue.yo & 'smoke' & bl: $\mathrm{cr}$ & puiyo & 'smoke' \\
\hline wung.car.ne & 'speak' & bl: cr & wanggandi & 'to speak' \\
\hline pull.le & 'star' & $\mathrm{bl}: \mathrm{cr}$ & purle & 'star' \\
\hline tin.to & 'sun' & $\mathrm{bl}: \mathrm{cr}$ & tindo & 'sun' \\
\hline pine.ye & 'morning' & bl: $\mathrm{cr}$ & panyi & 'early in the morning' \\
\hline i.char.ne & 'tired' & & $\mathrm{bl}: \mathrm{cr}$ & ngaityarni 'tired; wearied' \\
\hline yul.to & 'frog' & bl: cr & (no identified c & iterpart) ${ }^{12}$ \\
\hline war.rar.te & 'tadpole' & $\mathrm{bl}: \mathrm{cr}$ & (no identified $c$ & terpart) \\
\hline cow.we & 'water' & bl: gar & kauwe & 'water' \\
\hline war & 'where is it?' & $\mathrm{bl}: \mathrm{cr}$ & $w a$ & 'where?' \\
\hline war.re & 'wind' & bl: $\mathrm{cr}$ & warri & 'wind' \\
\hline ar.mither & 'black woman' & $\mathrm{bl}: \mathrm{cr}$ & ngammaitya & 'woman generally' \\
\hline \multicolumn{2}{|c|}{ i.thoe.ar.mi.ther 'my wife' } & $\mathrm{bl}: \mathrm{cr}$ & ngaityo ngamma & 'my woman' . \\
\hline \multicolumn{2}{|c|}{ nin.co.ar.mi.ther 'your wife' } & bl: cr & ninko ngammait & your woman' \\
\hline \multirow{3}{*}{$\begin{array}{l}\text { pie.ther } \\
\text { ar.rer }\end{array}$} & ld woman' & bl: $c r$ & paityabulti & 'old woman' \\
\hline & 'wood' & bl: $c r$ & $\begin{array}{l}\text { ngarra } \\
\text { stump; stick' }\end{array}$ & 'piece of burnt wood; \\
\hline & & & karra & 'red gum tree' \\
\hline
\end{tabular}

In addition, cue.wer 'crow' appears in the handwritten manusrcript, but seems to have been inadertently omitted by Plomley. It is clearly another representation of kua 'crow' which appears in T\&S (1840).

Robinson also records two short sentences, only one of which is included within Plomley (1976):

1. I.tho.nin.to.pie.ar.rer.war.rer 'Do you understand my talk?'

cf corresponding Kaurna sentences constructed following similar forms in Teichelmann \& Schürmann (1840):

Ngaityo nindo paiarendi warra? 'Do you understand my talk?'

and

Ngaityo nindo paiari warra? 'Did you understand my talk?

2. yun.char.le.nin.co.what.te 'What's your name?'

'What's your name?' has been recorded by Teichelmann \& Schürmann (1840) and Teichelmann (1857) as:

\footnotetext{
${ }^{12}$ Compare with Wyatt's (1879) ngoorto 'a frog'. Robinson had difficulty in transcribing the initial 'ng' sound. It is just possible that in this instance he wrote it as ' $y$ ', though in all other cases he simply left it off.
} 
Ngaintya ninna narri?

Nganna narri ninko?

Ninko narri ngaintya?

Ninna narri ngaintya?

None of these accord closely with Robinson's version, though the segment nin.co clearly relates to ninko 'your'. The German Kaurna sources record the words narri 'name' and mityi 'name' used by people in the north and at Encounter Bay. However, Wyatt (1879: 21) records watte 'name' in accord with Robinson's what.te. That leaves the first half of the expression, yun.char.le which bears a slight resemblance to ngaintya 'what', remembering that Robinson is unable to transcribe initial 'ng'. There is a suffix in Kaurna -rli 'to resemble; -like'. Perhaps Robinson's yun.char.le is equivalent to ngaintyarli ' which might translate as 'what like?'. However, this form with the -rli suffix attached is not found in any of the Kaurna sources.

Almost all the words recorded in Robinson's wordlist have clear and readily identifiable counterparts in Kaurna. However, there are a few words eg. war.rar.te 'tadpole' and mo.ker mo.ker 'kangaroo rat' for which terms were never recorded by Teichelmann \& Schurmann (1840) or by other observers. Teichelmann \& Schürmann (1840) record kanto 'bullfrog' but did not record yulto 'frog', which appears in Robinson.

For most of these vocabulary items appearing on pages 159-164 of the Robinson manuscripts, another Ben Lomond word is also recorded by Charles Robinson in addition to the Kaurna word. The Kaurna words appear quite out of place within the wordlists published by Plomley for the reasons given earlier. The true Ben Lomond words are more similar to other Tasmanian words and many have clear cognates with other Tasmanian languages. For example, Charles Robinson gives both le.brun.ne and wal.le for 'house'. Le.brun.ne is clearly cognate with words recorded by a number of observers as follows:

$\begin{array}{llll}\text { GA Robinson } & \text { lee.brun.ne } & \text { 'hut, house' } & \text { (Piper River, NE Tas) } \\ \text { GA Robinson } & \text { lee.brun.ne } & \text { 'hut' } & \text { (Port Dalrymple, Nth Tas) } \\ \text { GA Robinson } & \text { lee.brun.ne } & \text { 'house' } & \text { (eastern tribes) } \\ \text { GA Robinson } & \text { le.brun.ne } & \text { 'hut' } & \text { (northern tribes) } \\ \text { Sterling } & \text { leebrerne } & \text { 'house' } & \text { (Piper River) } \\ \text { Milligan } & \text { leprena } & \text { 'house, hut; } & \text { (Oyster Bay) } \\ \text { Jorgenson } & \text { leprena } & \text { 'hut' } & \text { (eastern tribes) } \\ \text { Backhouse } & \text { leprennie } & \text { 'breakwind, house, hut, place of rest' } \\ \text { Walker } & \text { lyprenny } & \text { 'house' } & \\ \text { Milligan } & \text { lebrina, leebra } & \text { 'house, hut' } & \text { (west. or northwestern tribes) } \\ \text { Sterling } & \text { lo'penarne } & \text { 'house' } & \\ \text { Jorgenson } & \text { tama lebirinna } & \text { 'hut' } & \text { (northern tribes) } \\ \text { Jorgenson } & \text { tama leeberinna } & \text { 'breakwind, hut' } & \text { (Circular Head, NW Tas) }\end{array}$

Numerous other words for 'house' are recorded from across Tasmania, but none of them are anything like wal.le 'house'.

Similarly, Charles Robinson gives both te.wer.rut.ten.ner 'wind' and war.re 'wind' as Ben Lomond words. Te.wer.rut.ten.ner is clearly related to words recorded by other observers, but war.re 'wind' stands out on its own. 
The evidence pointing to these words cited above being Kaurna is very strong indeed. The morphological evidence discussed on page 2 is overwhelming. Even the minimal sentence data provided is analysable to a large extent. This added to the fact that almost every word occurring in the list can be accounted for with a clear counterpart in Teichelmann \& Schürmann (1840) provides irrefutable evidence that the wordlist in question is in fact Kaurna.

\section{The context in which Robinson's Kaurna wordlist was recorded}

Plomley attributes the recording of thirteen wordlists to Charles Robinson, including two which he says belong to the Ben Lomond area of north-east Tasmania. These vocabularies appear in notebooks and on sheets of paper. Plomley observes that in relation to Charles Robinson's materials 'it should be noted that the lists are not always clearly labelled as to tribal origin (and possibly are not always properly associated in the collation), and that some are not labelled at all'. ${ }^{13}$

Robinson's Kaurna wordlist is compiled on pages $159^{14}, 160,163$ and 164 of the Robinson Papers Volume 64, Part 6. There is in fact no indication on these manuscript pages themselves as to when, where and from whom the words were recorded and which language they were thought to be. However, within the same volume on preceding pages, in what appears to be the same handwriting (i.e. Charles'), the wordlist on page $101^{15}$ is headed 'Benlomond' with the later addition in George Augustus Robinson's handwriting 'JanY 1838 F.I'. and on page 105 'Charles'. Plomley notes this (1976: 21) and has assumed, perhaps on the basis of these notations on preceding pages, that the Kaurna words also belong to the Ben Lomond area. Jumbling and re-ordering of the original manuscript has perhaps also contributed to the mis-identification of the Kaurna wordlist. Whilst Plomley attributes the majority of the Kaurna words to Charles Robinson, several are attributed to his father George Augustus Robinson. This is curious as all the words belong to the same wordlist and are written in the same handwriting which is definitely not that of George Augustus Robinson. ${ }^{16}$

According to Plomley, Charles Robinson arrived in Tasmania in 1826 at the age of nine years. ${ }^{17} \mathrm{He}$ accompanied his father on expeditions to round up the remaining Tasmanians in 1830, 1832 and 1833/34. He then lived on Flinders Island with his father, who was appointed commandant of Wybalenna, the Flinders Island Aboriginal

\footnotetext{
${ }^{13}$ Plomley, 1976: 22.

${ }^{14}$ These page numbers have been written over the top of the original page numbers which are faint and illegible. Page 163 for instance, appears to have been originally numbered 42 .

${ }^{15}$ The numbering of Charles Robinson's wordlists is confusing. Some pages have three different numbers on them. It would appear that the page numbers provided here have been added at a later date. In the 'Benlomond Jan 1838 F.I.' wordlist referred to here bears the original numbering of pages 1 to 10 numbered in the opposite corners as in an open notebook. The numbers added later are 101 to 104,113-114, 117-118, 115-116 in that order, thus jumbling the original ordering of the wordlist. Library microfilm frame numbers at the bottom of the pages are $837-840,849-850,853-854,851-852$ following the same sequence of the numbers added later.

${ }^{16}$ p.c. Ian Clark, 1994.

${ }^{17}$ Plomley 1976: 22.
} 
settlement, from October 1835 to February 1839. Charles Robinson's wordlists were most likely compiled at Wybalenna from material elicited from residents there.

But how did so many Kauma words come to be recorded at Flinders Island and become part of the Tasmanian corpus? To answer this question we must turn to history and Robinson's journals in particular.

\section{The historical context}

Frequent movements of Aboriginal people from Albany to Bass Strait, and occasionally even further afield were associated with the frenzied activities of sealers and whalers during the early part of the nineteenth century. ${ }^{18}$ This activity actually preceded any official white settlement in Victoria, South Australia and Western Australia. ${ }^{19}$ The sealers obtained Aboriginal women for their sexual favours but also for their assistance in hunting of seals and other game and to collect bush foods for them. Some women were kept in a state of slavery. The women were obtained chiefly from Tasmania, but also from Victoria, South Australia and Western Australia. Occasionally Aboriginal men were also living with sealers and engaged in their sealing activities, including a number of Aboriginal men from Port Jackson (Sydney). Hence, there was frequent contact between indigenous Tasmanians and Kaurna people from the coastal region south of Adelaide as well as with members of other Aboriginal groups from the southern coasts of mainland Australia.

\footnotetext{
${ }^{18}$ Whaling and sealing activity extended as far as Amsterdam and St Paul Islands, roughly midway between Western Australia and South Africa in the west and to the South Island of New Zealand and its surrounding islands in the east. It is known that occasionally Tasmanian women accompanied sealers to Amsterdam and St Paul Islands in the Indian Ocean. For instance, five Tasmanian women and three children accompanied sealers to St Paul on the Hunter in 1825. From St Paul the women went to Ile de France (Mauritius). One woman and a child died there. Another child was allowed to remain there with his father, a sealer. The other women and child returned to Tasmania via Sydney in March 1827. (Plomley, 1987, p. 280) In 1832 Backhouse, a Quaker who visited Flinders Island, came across some Tasmanian women who knew some French which they had learned in Mauritius. (Plomley, 1966, p. 686)

${ }_{14}$ The sealing industry in the Southern Ocean closely followed Flinders' and Bass's salvage mission in 1797 of the Sydney Cove, wrecked in the Furneaux Islands in Bass Strait. On his return to Port Jackson, Flinders reported on the abundance of fur seals on islands in Bass Strait (Plomley \& Henley, 1990, p. 2). The first Australian sealing vessel operating in Bass Strait sailed in 1798 (Cumpston, 1970, p. 73) The sealers and whalers themselves seem to have left no written records chronicling their activities. Most were illiterate. However life in the southern oceans can be pieced together from the writings of passing observers and records of shipping movements to and from the ports of Sydney and Hobart. Cumpston (1970) documents several voyages each year to Kangaroo Island by sealers and whalers from 1803 onwards when the American ship, the Union sailed to Kangaroo Island and spent more than four months there whilst building a second ship and sheltering from the winter. It is possible that sealing vessels could have visited Kangaroo Island prior to its 'discovery' by Flinders in 1802 (Nunn, 1989, p. 11f). An American ship, the Elligood is known to have reached King George Sound (Albany) in 1800 and it is likely that the ship also visited Kangaroo Island (Cumpston, 1970, p. 7). The larger American Nantucket ships provided a more or less reliable supply line and transport for the sealers, though many sealers traversed the southern ocean along vast stretches of the Australian coast in open whale boats. Much of what we know about the activities of the sealers comes from the journals of George Augustus Robinson published by Plomley $(1966 ; 1987)$.
} 
Kangaroo Island was visited frequently by sealers, as it was the main source of salt used for curing the seal skins. It was established as a base for unruly elements of the sealing industry, some of whom were runaway convicts. Because Kangaroo Island was beyond the reach of the law and because it appears to have been uninhabited by Aboriginal people for the last 2,000 years, it served as a safe haven for the sealers, who were able to kidnap Aboriginal women from Tasmania and the mainland and then retreat there without fear of reprisal from the women's husbands and kin. We know for sure that both Tasmanian women and Kaurna women were present on Kangaroo Island. Most likely the first Aboriginal women on Kangaroo Island were Tasmanians. Peron (1816) notes that the traders, who visited the island [Kangaroo Island] brought with them a Tasmanian lubra for a consideration'. The captain of a passing ship [Sutherland] reported in 1819 that Europeans living on Kangaroo Island who 'have carried their daring acts to an extreme, venturing on the mainland in their boats and seizing on the natives, particularly the women, and keeping them in a state of slavery, cruelly treating them on every trifling occasion ${ }^{\prime 20}$ Later, it would appear that Kaurna women were the most numerous amongst the Aboriginal women on Kangaroo Island as the result of local kidnapping operations carried out on the mainland, principally in the Rapid BayCape Jervis region where the coast was more sheltered. Like the Tasmanian women, South Australian women were also transported over a vast area across the Southern Ocean. ${ }^{21}$ Specific accounts probably represent just the 'tip of the iceberg' since few accounts were written and few records survive from this era.

Philip Clarke discusses the early interaction between the sealers and whalers and Aborigines in the southern oceans, focussing on Kangaroo Island. He notes that in 1820 , there were an estimated fifty sealers with about a hundred Aboriginal wives and children, living in the Bass Straits to Kangaroo Island region'. ${ }^{22}$

Some of the Kaurna women kidnapped from the southern Kaurna region ended up living with sealers in Bass Strait. In 1831, Robinson noted that there were Aboriginal

\footnotetext{
${ }^{20}$ Moore cited in Clarke, 1994: 7.

${ }^{21}$ In 1822 a sealer was encountered on the South Island of New Zealand. 'The man Stuart had come from Kangaroo Island with a wife of the country and two children to settle in New Zealand; but having with his family been taken prisoner by the natives [Maoris], he had adopted their customs [and] was employed by the chiefs... as a pilot...for finding all the different hiding places of the Americans' (Cumpston, 1970, p. 63). It is unclear exactly when this woman, likely to have been a Kaurna woman, went to New Zealand. It is also known that in 1823 another woman from Kangaroo Island (possibly a Kaurna woman) was stranded on the South Island of New Zealand for a period of eight months with her small child. The other members of her sealing party belonging to an American ship, the General Gates, had been killed by Maoris. This South Australian woman returned to Sydney in April 1824. (Cumpston, 1970, p. 66). It is possible that these two accounts refer to the same woman, though the dates suggest otherwise.

${ }^{22}$ Clarke 1994: 3.
} 


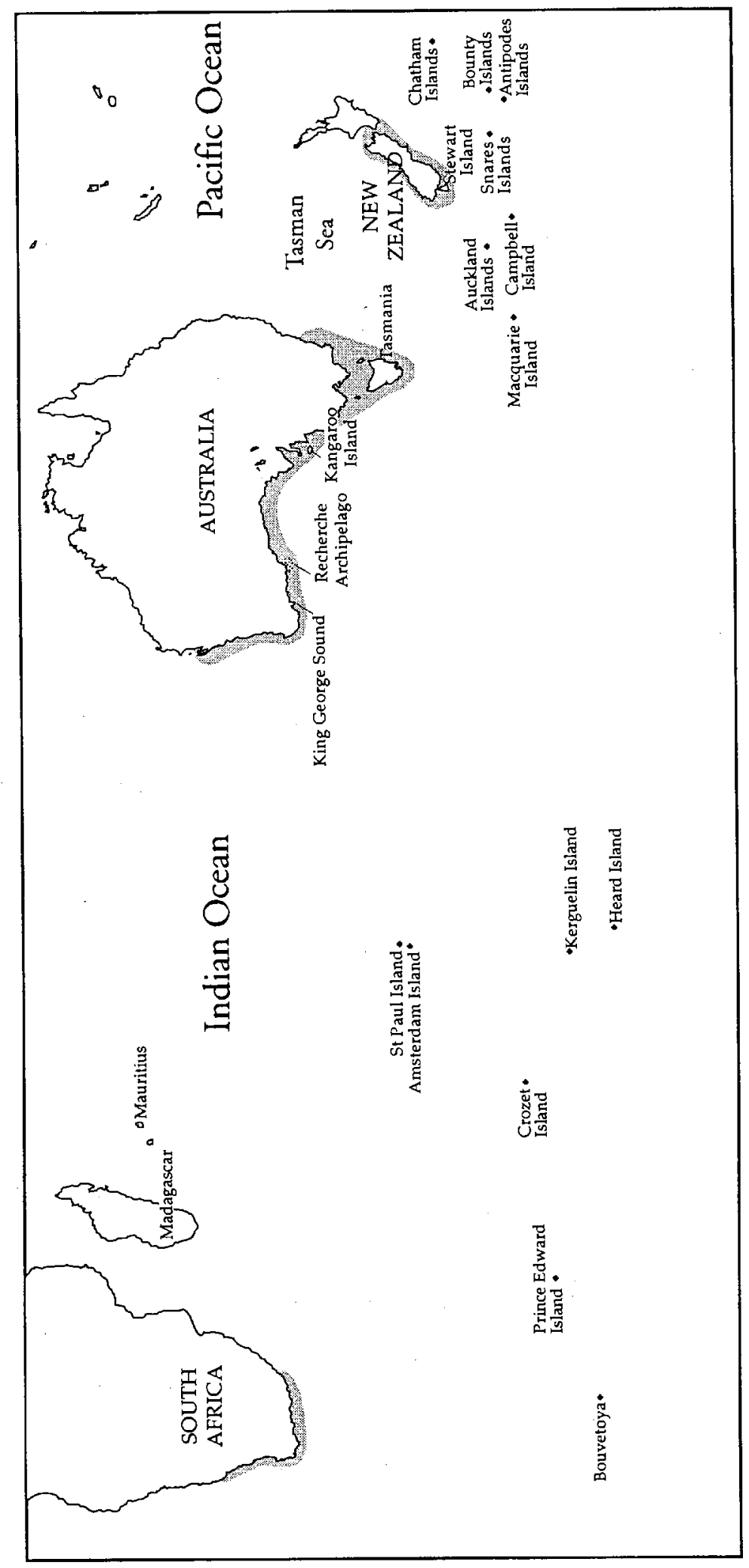

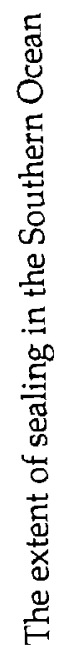


women from Kangaroo Island present on islands in the Kents Group in the eastern Bass Straits, north of Flinders Island. ${ }^{23}$ One of these women, Emue or Emma, was a Kaurna woman who was living with a sealer named John Anderson, alias Abyssinia Jack Anderson told Robinson that:

[he] has a black woman living with him, which he got from off the main on the coast of New Holland opposite to Kangaroo Island and has lived with her ever since. Says he has ten children by her, five of whom are alive. Got a black boy from the main, son to this woman, about four years since. ${ }^{24}$

On 23rd July 1836, Robinson reports that:

Corporal Ramsay returned to the settlement from the Sisters Islands [immediately to the north of Flinders Island] having removed the sealers, who offered no resistance. They had been on the islands about a fortnight...They had two boats. Abyssinia Jack had charge of one with some Hew Holland women and also VDI [Tasmanian] women named [ ]. The New Holland women were the same that had been stolen from their country adjacent to Kangaroo Island by George Meredith jnr of Oyster Bay...The sealers had several halfcaste children on board of their boats. There were three men in the boat, Abyssinia Jack, Everett and another...A Abyssinia Jack and another sealer stop on Woody Island. They reported that there was three men on Gun Carriage [island adjacent to Woody Island in between Flinders and Cape Barren Islands]. They had with them several New Holland women. ${ }^{25}$

In 1837 Emue was still living with Anderson, then on Woody Island, in between Flinders and Cape Barren Island. Robinson's journal entry of 10 January 1837 contains the following:

\section{Woody Isle:}

Abyssinia Jack and three women native of New Holland; one with Everett one infant; with Abyssinia a woman Emue and three children; a woman native of Spencers Gulf has been left by Dutton, this woman has a boy by a black man, she wishes to leave the sealers. ${ }^{26}$

This latter woman, Kalloongoo, also named Sarah by the sealers and renamed Charlotte by Robinson, is crucial to the story of Robinson's Kaurna wordlist. Plomley's annotations to Robinson's journal for 1 June 1837 note that:

Corporal Miller left the settlement on the morning of 31 May for Woody Island and reached there that evening. He was accompanied by two aboriginal women, Rebecca and Matilda. On arrival at Woody Island, Miller interviewed the one sealer there, John Anderson, who told him that sometimes another sealer lived there too, but that he had 'gone to port'. There were two native women and three children on the island, of whom one woman and two children belonged to Anderson. The other woman, after talking to the women from the settlement, was willing to quit the island on the understanding that she would be conveyed to her own country, i.e. New Holland. She was known as Sarah or Charlotte, and was about twenty years old. ${ }^{27}$

\footnotetext{
${ }^{23}$ Robinson in Plomley; 1966: 327, 335.

${ }^{24}$ in Plomley, 1966: 327.

${ }^{25}$ in Plomley, 1987: 366-67.

${ }^{26}$ in Plomley, 1987: 416.

${ }^{27}$ in Plomley, 1987: 695.
} 
On June 1st 1837, Kalloongoo was brought to Robinson's settlement at Flinder's Island and remained there until the 25 February 1839 when she was taken by Robinson to Port Phillip (Melbourne). Whilst at Flinders Island, Kalloongoo lived in Robinson's house and worked for him as a domestic servant, and thus is the most likely source of the Kaurna wordlist. It is most likely that Charles Robinson recorded the wordlist somewhere between June 1837 and February 1839, as he was in constant contact with her during this period.

On arrival at Flinders Island, Kalloongoo gave a lengthy account to Robinson of how she was kidnapped and her subsequent life with sealers on Kangaroo Island and in Bass Strait. In addition she provided specific details of her origins. Her interview with Robinson, as recorded in Robinson's journal for June 2nd 1837, is provided here in full:

Interrogated the woman who arrived last night from Woody Island; result as follows-(1) KAL.LOON.GOO, (2) COW.WER.PITE.YER, (3) WIN.DEER.RER alias Sarah an aboriginal female of New Holland, the point opposite to Kangaroo Island, the west point of Port Lincoln. Was forcibly taken from her country by a sealer named James Allan who in company with another sealer Bill Johnson (this man was drowned subsequent to my visit to Port Philip) conveyed her across to Kangaroo Island where she remained for a considerable time until she was seized upon by Johnson and forced on board the schooner Henry J Griffith owner and master and brought to the straits, when Johnson sold her to Bill Dutton, who had subsequently abandoned her. She had a child by Dutton a girl which he took away with him. The woman states that at the time she was seized and torn from her country, Allan the sealer was led or guided to her encampment and where her mother and sister then was by two blackfellows her countrymen but not her tribe and who had been living with the sealers on the island [Kangaroo Island]. Said the blackfellows came sneaking and laid hold of my hand; the other girl ran away. The white man put a rope around my neck like a dog, tie up my hands. We slept in the bush one night and they then tied my legs. In the morning we went to the boat. They took me then to Kangaroo Island. She remained there a long time until she was brought away in the schooner [Henry owned by J. Griffith] to the straits. She said there were several New Holland [mainlander] black men on Kangaroo Island. Said two of them died from eating seal; her brother died also from eating seal. Said the sealers beat the black women plenty; they cut a piece of flesh off a woman's buttock; cut off a boy's ear, Emue's boy. This woman [Emue] is now on Woody Island with Abyssinia Jack. The boy died in consequence of his wounds. They cut them with broad sealer's knives. Said they tied them up and beat them and beat them with ropes. ${ }^{29}$ Bill Dutton beat her plenty. Said the sealers got drunk plenty and women get drunk too. Said the country where she came from was called BAT.BUN.GER [Patpangga = Rapid Bay] YANG.GAL.LALE.LAR [Yankalilla]. It is situate at the west point of St. Vincents Gulf. Said that Emue's brother was her husband. It is on the sea coast; there is a long sandy beach with three rivers. MAN.NUNE.GAR is the name of the country where she was born. Kangaroo island is called DIRKI.YER.TUN.GER.YER.TER; WAT.ER.KER.TER, an island. (YAR.PER, a hole; called the hole in the cartilage of her nose YAR.PER.) (1) WHIRLE (2) WHIR.LE, house. Fire, KIR.LER. Wood, (1) NAR.RER (2) NAR.RAR.

\footnotetext{
${ }^{2 h}$ This account of cruelty given by Kalloongoo is closely corroborated by Anderson's and Constable Munro's versions of the same events documented by Robinson some years earlier in 1831 (Plomley ed. 1966, p. 357, 360, 462, 1010).
} 
This aboriginal female of NH KAL.LOON.GOO has a hole through the cartilage of her nose. She relates the following circumstances in reference to her removal from Kangaroo Island. She said one day the schooner Henry John Griffith master and owner came to Kangaroo Island. Allan was away at this time at another part of the island. Said that Johnson tied her hands aand feet and put her on board of the schooner, when he and Harry Wally came away in the schooner to the islands in the straits. A sealer Harry Wally assisted in tying her. Subsequently Johnson sold her to Bill Dutton by whom she had a female child a girl. She had had a male child by a Sydney black a sealer. This child is the one now with her and is about five years of age. Bill Dutton stopped on Woody Island with Abyssinia Jack. He has left about ten moons, has gone away and married a white woman. He took his child the girl with him. She had heard this. He has gone whaling. The boy was born at a rock near to the Julians. She had the girl first by Bill Dutton. Said she was a big girl when Allan took her away from her own country. In answer to a question, 'do you like this place', she said 'yes!' 'Do you want to go to Woody Island?', 'no, it is no good place, there is nothing there at all'. She got little to eat. Bill Dutton beat her with a rope. She was glad she had got away. In answer to several questions about God she answered she never learnt him, she did not know. The woman's boy is about five years of age and is very interesting child. The features are European cast, thin lips and small feataures, and appears intelligent. So also does the mother. The woman's features are similar to the boy's. So soon as it was known at the native settlement that a New Holland woman had arrived all the native inhabitants were in motion and an evident excitement was created. Several of the native men came to my quarters but the greater part kept away from bashfulness. Before breakfast I walked with her to the native cottages and introuced her to the aborigines, and she met with a hearty welcome from those generous and simple hearted people. She appeared much delighted with her reception and there appeared a reciprocal feeling between this stranger and the resident aborigines. She brought a bitch and two pups with her. This morning she drew here rations from the store and was put on the strength of the establishment from yesterday the first of June inst. Much curiosity prevailed on the part of the aborigines, and constant visits was made throughout the day at my house to see the stranger. About noon her son arrived in the boat. I shewed the various kinds of work performed by the male aborigines, the cultivated land, the fencing, the road making, and the large heap of grass collected by the females, their knitting and domestic work, with the whole of which she appeared highly delighted and said she should like to learn to work like them. At $6 \mathrm{pm}$ she accompanied me to the evening school and here she appeared to be quite overcome with astonishment at what she witnessed. This was a new scene, an epocha she had not possible conceived. Here she beheld people of her own colour engaged at learning what she could not comprehend, native children teaching native men and women. Heard the whole in one united chorus singing the praises of God, of that being of whom she had not heard and of whom she acknowledged she had not the slightest conception. All was wonder to her poor untutored mind. I shall not easily forget with what astonishment she looked when the congregation began to sing, and it appeared equally a matter of surprise to her when the native men stood up to pray. She said she wished to learn and I instructed her in the alphabet, I suppose the first time in her life. 


\section{June Sat}

This morning the aboriginal female of New Holland was brought to the office and interrogated by the Commandant in the presence of the storekeeper $\mathrm{Mr} \mathrm{L}$ Dickenson and Mr Clark the catechist and which was signed by those gentlemen and is herewith annexed by which it will be seen that this poor creature has been cruelly treated and left in total ignorance of the Being of a God. She made the statement and answered the questions without the least embarrassment....This evening Charlotte was again surprised at what she witnessed at our family worship. On the arrival of this woman a new name was given her i.e. Charlotte in lieu of Sarah by which latter she was called by the sealers, and it has been my practice to give new names to all who join the settlement from this class of individuals. She is very docile and quiet and appears industrious. She this day cleaned out my office. ${ }^{29}$

\section{Kalloongoo, a Kaurna woman from the region south of Adelaide, and not from Port Lincoln}

Before proceeding further, it is necessary to clear up a point of confusion inherent in Robinson's journal entry, and perpetuated in a number of secondary sources published since. Robinson's interview with Kalloongoo quoted above begins with the statement that 'KAL.LOON.GOO, (2) COW.WER.PITE.YER, (3) WIN.DEER.RER alias Sarah [is] an aboriginal female of New Holland, the point opposite to Kangaroo Island, the west point of Port Lincoln'. Cumpston referring to this journal entry of Robinson's reiterates that 'Dutton had obtained a New Holland woman (from Port Lincoln) named Kal.loon.goo (Sarah/Charlotte)' ${ }^{3(t)}$ Barwick also referring to Robinson's journal, this time for 9th January 1837, makes the statement that two of the women on Gun Carriage Island in the Furneaux Group between Flinders and Cape Barren Islands 'were certainly from Port Lincoln' ${ }^{\prime 31}$ and cites personal communication with Plomley that 'Kalloongoo or Sarah (then renamed Charlotte) was originally kidnapped from Port Lincoln (where she had been married to a brother of the woman Emue or Emme who became the wife of the Abyssinia Jack' alias John Anderson)'.32 Mollison, also drawing on Robinson's journals, refers to Kalloongoo as coming from Port Lincoln. ${ }^{33}$

However, later in the interview with Robinson, Kalloongoo 'said the country where she came from was called BAT.BUN.GER [Patpangga = Rapid Bay] YANG.GAL. LALE.LAR [Yankalilla]. It is situate at the west point of St. Vincents Gulf'. Rapid Bay and Yankalilla are located to the south of Adelaide, north of Cape Jervis. The reference to Kalloongoo coming from Port Lincoln then is probably due to Robinson's lack of knowledge of the geography of the South Australian coast. Robinson recorded this interview in 1837, one year after the establishment of the South Australian colony, when Port Lincoln was nothing more than a name and a dot on a map. The town of Port Lincoln was not surveyed until 1840.

\footnotetext{
${ }^{24}$ in Plomley, 1987, pp. 445-447.

${ }^{30}$ Cumpston 1970, p. 170.

${ }^{31}$ Barwick 1985, p. 212.

${ }^{32}$ Barwick 1985, p. 231.

${ }^{33}$ Mollison 1976.
} 
The language data recorded by Robinson in this interview further confirms that Kalloongoo was a Kaurna speaker. The words recorded are readily identifiable as Kaurna words recorded by Teichelmann \& Schürmann (1840):

$\begin{array}{llll}\text { Robinson's Journal } & \text { Gloss } & \text { T \& S (1840) } & \text { Gloss } \\ \text { yap.per } & \text { 'a hole' } & \text { yappa } & \text { 'hole' } \\ \text { whirle; whirle } & \text { 'house' } & \text { wodli }{ }^{34} & \text { 'house' } \\ \text { kir.ler } & \text { 'fire' } & \text { gadla } & \text { 'fire' } \\ \text { nar.rer; nar.rar } & \text { 'wood' } & \text { ngarra } & \text { 'piece of burnt wood, } \\ & & & \text { stump, stick' }\end{array}$

The name recorded for Kangaroo Island, Dirki.yer.tun.ger.yer.ter, is possibly a misunderstanding. Kalloongoo might have said tikki yertangga yerta 'lived on the land (on) the land', possibly meaning that she came from the mainland. Wat.tar.cut.ter is also recorded for 'an island' in Charles Robinson's wordlist, whilst a similar form wattegakal is given by Gaimard (1833) for 'island'. Teichelmann \& Schürmann (1840) document Karta as the name for Kangaroo Island, though they did not record a word for 'island' in general.

James Allen, Kalloongoo's abductor and master on Kangaroo Island, was engaged in the sealing industry from $1817 .{ }^{36}$ However, she must have been kidnapped some time after 1823 since her co-abductor, William Johnson was on board a sealing vessel, the Alligator in $1823 .^{37}$ In 1831, Johnson told Robinson that he had been sealing for seven to nine years. ${ }^{38}$ She would have been transported from Kangaroo Island to Bass Strait aboard the Henry sometime between March 1829 and March 1834. We can say this because the Henry was launched in 1827 and made her first voyage to Kangaroo Island in March 1829. The Henry made at least seven voyages to Kangaroo Island before she was wrecked at Portland in September 1834.

We can use additional information to pin down the date even further. Plomley and Henley estimate that Sophia, Kalloongoo's daughter to Bill Dutton of Portland, was born about $1830 .^{39}$ Dutton first went sealing in 1828 and was landed at Portland Bay (in Victoria) in December of that year. Note that in 1837, Robinson reported that at the time Kalloongoo had a son, Johnny Franklin, who was estimated to have been five years old, so Johnny Franklin would have been born in about 1832. It is also known from Kalloongoo's interview that Johnny Franklin was born on a rock near the Julia Percy Islands near Portland and that Sophia, was born before Johnny Franklin. So for Sophia

\footnotetext{
${ }^{34}$ Non pre-stopped forms recorded in other sources: worli 'house' (Teichelmann, 1857); wer-lie 'house' (Williams, 1840); werle 'house' (Wyatt, 1879); walle 'house' (Gaimard, 1833) are closer to Robinson's whirle 'house'.

${ }^{35}$ Similarly, other observers record non pre-stopped forms garla 'fire' (Teichelmann, 1857); cur-la 'fire' (Williams, 1840); kerla 'firewood' (Wyatt, 1879) again more closely approximating Robinson's kir.ler 'fire'.

${ }^{36}$ Cumpston, 1970, p. 44

${ }^{37}$ Cumpston, 1970, p. 170

${ }^{36}$ Plomley, 1966, p. 1013

${ }^{39}$ Plomely and Henley 1990, p. 26.
} 


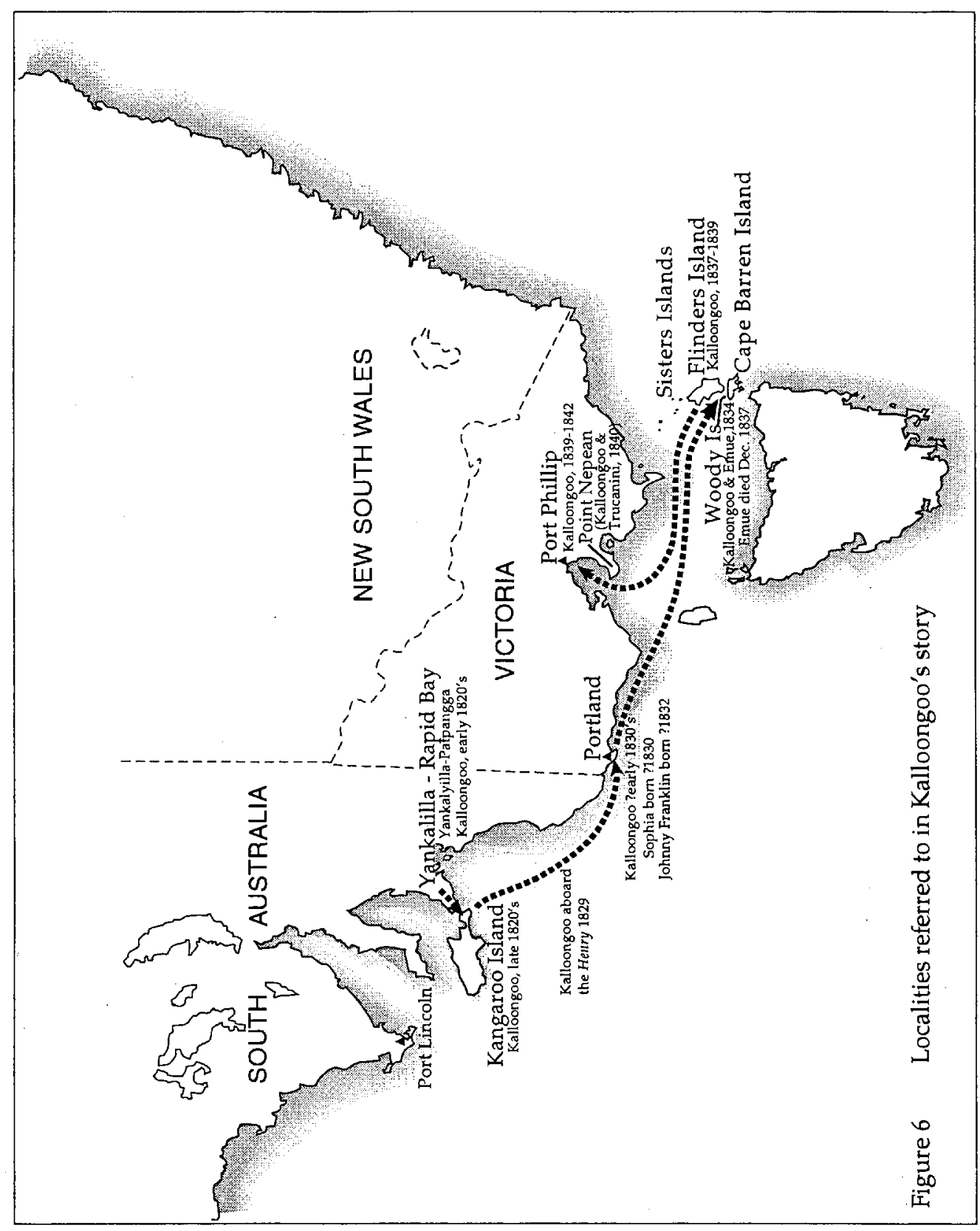


to have been born before Johnny Franklin in about 1830, it is most likely that Kalloongoo was transported to Portland in the Henry on its first voyage to Kangaroo Island in 1829.

Kalloongoo herself was thought to have been about twenty years old in $1837 .{ }^{40}$ If that was the case, she would have been a child when she was abducted. However, that in itself would not have been unusual. Robinson's journals document many cases of sealers kidnapping children and keeping them as slaves for many years.

Kalloongoo was reported to be still in Port Philip (Melbourne) in 1842, where she appears to have been a close friend of Trucanini. In 1840 they had gone off together and were living with two shepherds at Point Nepean at the entrance to Port Philip Bay. ${ }^{41}$ Following the killing of two whalers by a group of Tasmanians that Robinson had brought to Port Philip, Trucanini and the other Tasmanians were sent back to Flinders Island, but Kalloongoo and her son, Johnny Franklin, remained at Port Philip. ${ }^{42}$

Emue or Emma, Kalloongoo's sister-in-law is generally assumed to come from Port Lincoln also, though Mollison, under the Anderson Family genealogy, states that she was of the Narrinyeri Group, South Australia. ${ }^{43}$ It is not clear on what basis Mollison claims that she was Narrinyeri. More likely she was Kaurna, though it is possible that she belonged to the neighbouring Narrinyeri (Ngarrindjeri) group. Later Mollison, drawing on Robinson's journals, refers to Emue as originating from the mainland opposite Kangaroo Island, and still later as coming from Spencer's Gulf. Emue had undoubtedly been abducted earlier than Kalloongoo because, as quoted earlier, in 1831 she was said to have 10 children to Abyssinia Jack, five of whom were with her on Gun Carriage Island. ${ }^{44}$ It is extremely unlikely that she had 10 children between 1823 and 1831. It seems that George Meredith Jnr was Emue's abductor:

\section{July 1836}

They had two boats. Abyssinia Jack had charge of one with some New Holland women and also VDL women ... The New Holland women were the same that had been stolen from their country adjacent to Kangaroo Island by George Meredith Jnr of Oyster Bay. ${ }^{45}$

Emue died at Woody Island in December $1837 .^{46}$

\section{The importance of Robinson's Kaurna wordlist}

The existence of an early Kaurna wordlist recorded far from Kaurna territory is an interesting, but not unique phenomenon. The first Kaurna wordlist ever to have been transcribed was recorded by a French zoologist, M. Gaimard, aboard the Astrolabe in King George Sound (Albany) in south west Western Australia, ${ }^{47}$ This wordlist of 160 words was also recorded from a Kaurna person taken there by sealers in 1826 . At the

\footnotetext{
40 Plomley, 1987, p. 695

${ }^{41}$ Rae Ellis, 1981, p. 100

${ }^{42}$ Rae Ellis, 1981, p. 119

${ }^{43}$ see Barwick, 1985, pp. 212, 231 and Mollison 1976.

${ }^{44}$ Plomley, 1966, p. 327

${ }^{45}$ Plomley, 1987, p. 366

"' Barwick 1985, p. 231

${ }^{47}$ Gaimard, 1833
} 
same time Gaimard also recorded a Tasmanian wordlist. However, Gaimard's Kaurna wordlist is the topic of another paper. ${ }^{48}$

As we have seen, almost all of the words in Robinson's Kaurna wordlist are already known to us in more reliable sources, especially Teichelmann \& Schürmann (1840). How then is Robinson's Kaurna wordlist important?

Firstly, there are several words, yul.to 'frog', war.rar.te 'tadpole' and mo.ker mo.ker 'kangaroo rat' in Robinson's Kaurna wordlist which were not recorded in any of the other Kaurna sources. In fact, no term for 'tadpole' is recorded in the other Kaurna sources, though a different word, mudatj 'tadpole' is recorded in Narrunga, a closely related language. Occasionally, an additional form of an existing word, such as yar.to yar.to 'baby' related to yerthondi 'to grow' has been recorded. At other times Robinson's recording gives an additional slant or another meaning of a word recorded by Teichelmann \& Schürmann. Par.cu.lar 'cold' compared with bakkadla 'hoar frost' is an example of this, though it could also be the result of misunderstanding.

Charles Robinson's transcriptions break the words into syllables, a practice both he and his father use regularly in transcribing Tasmanian words. Robinson has consistently omitted to write the initial velar nasal [N] irrespective of the following vowel. ${ }^{49}$ Vowels are transcribed inconsistently. The letter $\mathrm{i}$ is used for the diphthong [ai] as in i.thoe = ngaityo ' $m y$ ' and for the vowel [i] as in tin.to = tindo 'sun'.

The letter $u$ is used for the vowel [u] as in 'put' as well as the vowel $[\wp]$ as in 'but' The Kaurna vowel [i] is transcribed variously by the letters $i, e, e e, e r$ and a The Kaurna vowel [a] is transcribed variously by the letters ar, er, $u, e, a$ and $i$ The Kaurna vowel [u] is transcribed variously by the letters ou, $u$, ue, o and oe

The diphthong [ai] is transcribed as i, ie, yhe and $y$

Note for example:

$\begin{array}{lll}\text { i.thoe } & =\text { ngaityo } & \text { 'I' } \\ \text { pie.ther.pull.ta } & =\text { paityabulti } & \text { 'old woman' } \\ \text { caw.y.he } & =\text { kawai } & \text { 'come' } \\ \text { me.yo.cow.y } & =\text { meyu kawai } & \text { 'men are coming' }\end{array}$

The diphthong [au] is transcribed as ow, whilst the diphthong [ui] is transcribed as ue.

Robinson sometimes inserts a vowel within a consonant cluster. Note:

$\begin{array}{lll}\text { none.ta } & =\text { nurnti } & \text { 'away' } \\ \text { ule.ta } & =n g u l t i & \text { 'night' }\end{array}$

For some unknown reason, the final i vowel following $t$ is transcribed as a in both these words.

Consonants too, are transcribed inconsistently. The alveopalatal stop [ty] is transcribed as ch and th. The alveopalatal nasal [ny] is transcribed as n.y and ne.y. The velar stop [k] is transcribed variously as $c, k, c k, c k . c$ and $g$. Sometimes consonants are transcribed by a single consonant and at other times by a double consonant. It is

\footnotetext{
${ }^{48}$ Amery, forthcoming

${ }^{49}$ The i initial Kaurna words appear to be the only ones to appear in Plomley. This oddity caused Plomley (1976, p. 22) to question the accuracy and authenticity of Charles Robinson's transcriptions. He attributed these i intial words and other forms such as me.you 'man' to the influence of English.
} 
interesting that Robinson almost always transcribes stops as voiceless. Only rarely does he employ $\mathrm{d}$ or $\mathrm{g}$ and then it occurs mostly following a nasal. B appears not to be used at all in his transcription of Kaurna words.

In a few cases, Robinson's transcriptions can actually help in working out how to pronounce the word. For example, Robinson's transcription mu.rer.car.ne 'cry' indicates that the ' $r$ ' in murkandi 'to cry' is pronounced as an ' $r$ ' sound and the 'ur' sequence is not pronounced as in English slur. The spelling me.ther 'hot' tends to indicate that the ' $d$ ' in the word meda 'heat, flame, hot etc' is pronounced as an interdental stop [th]. It is difficult to know whether a ' $t$ ' or ' $d$ ' in Teichelmann \& Schürmann (1840) is pronounced as an interdental [th] and alveolar [t] or a retroflex stop [rt].

Where Teichelmann \& Schürmann have recorded a number of terms meaning more or less the same thing, Robinson's wordlist tends to indicate which terms were more commonly used, or which were commonly used by the southern Kaurna. Robinson's Kaurna wordlist provides additional evidence for the existence of a distinctive southern dialect, distinct from the dialect recorded by Teichelmann \& Schürmann (1840). There are a number of grounds for this:

1. It features the word mu.rane.ne 'run'. Teichelmann and Schürmann (1840) cite murrendi as a southern dialectal form as opposed to padnendi used in the north. Gaimard (1833) also records mourenn 'flee, run away'.

2. The present tense affix would appear to be $-n i$ in the southern dialect of Kaurna as all the verbs recorded by Robinson are listed with a final ne. There is no indication of the $\mathrm{d}$ in the present tense -ndi suffix recorded consistently by Teichelmann and Schürmann (1840). This is corroborated by other sources such as Gaimard and Wyatt.

3. The infrequent use of prestopping (eg. Robinson's cull.ar 'fire' c.f. T\&S gadla 'fire; Robinson's wal.le 'house' c.f. T\&S wodli 'house' etc.). Forms of these words without prestopping also appear in Gaimard and Wyatt. Prestopping is much more prevalent in dialects and languages to the north (eg Nukunu, Parnkalla), but is entirely absent in Ngarrindjeri to the east.

The existence of Charles Robinson's Kaurna wordlist has even more important linguistic implications for the languages of Tasmania. We know with some certainty the precise pronunciation of many of the Kaurna words he recorded. So this wordlist provides a good check on the quality and accuracy of Robinson's transcriptions and insights into the ways in which he tends to or prefers to represent sounds, or indeed to omit sounds altogether.

For instance, in a Tasmanian word transcribed by Charles Robinson, we simply don't know whether 'u' should be pronounced [u] as in 'put' or [§] as in 'but'. However, it may be safe to assume that final 'er' is pronounced [ $\wp$ ] or [ ] as in English 'butter' for this is the case in every instance of his Kaurna transcriptions. However, Kaurna does not allow consonant final words, so it might still be possible for Tasmanian words to end with an ' $r$ ' sound.

Similarly, George Augustus Robinson is known to have also recorded words from Victorian languages in the 1840 's. In the same way, these records may assist in

${ }^{50}$ Garimard 1833; Wyatt 1879. 
interpreting his work on Tasmanian languages. It is worth noting from the few Kaurna words George Augustus Robinson recorded, his transcriptions differed significantly from those of his son Charles. Note:

Charles Robinson
cull.ar
wal.le
ar.rer
war.tar cut.ter

George Augustus Robinson
kir.ler
whirle $\sim$ whir.le
nar.rer $\sim$ nar.rar
wat.ter.ker.ter

$$
\begin{aligned}
& \text { 'fire' } \\
& \text { 'house' } \\
& \text { 'wood' } \\
& \text { 'island' }
\end{aligned}
$$

Significantly, George Augustus transcribed the initial velar nasal in ngarra 'wood' as ' $n$ ' where Charles consistently omitted it.

However, despite his failings, this paper to some extent rehabilitates Charles Robinson's standing as a recorder of Tasmanian languages. Plomley, noting aberrant features in his recordings, is very critical of their quality and of Charles Robinson himself:

The following points suggest that little reliance can be placed upon Charles Robinson's work-

(a) In several places the record is incomplete, the English meanings of the aboriginal words having been omitted; as well, there is sometimes confusion in the record; and different copies may show differences of spelling of the native word.

(b) In a number of cases the word recorded appears to be wholly or partly a corruption of English (perhaps representing the 'pidgin' used by (some of) the natives on the settlement). The following appear to be such corruptions-

1. Words beginning with ' $i$ ', and particularly with 'i.tho(e)' (? = I so).

2. Some words beginning with ' 0 '.

3. Words such as 'me.you' (= man).

4. Words beginning with 'no' and with 'no i', which are English negatives.

Charles Robinson appears to have been handicapped in the compilation of his vocabularies by a lack of schooling and by a want of intelligence. Unless a word is supported by other records, it would probably be best to disregard it. ${ }^{51}$

Most of these 'corruptions' and some of the putative 'pidgin' features, though not all, are accounted for by the Kaurna wordlist. Points 1 and 3 levelled against Robinson can now be discounted entirely. It is now up to specialists of the Tasmanian languages to reassess the value of the remainder of Charles Robinson's work.

\section{Conclusion}

The linguistic evidence within Kalloongoo's interview with Robinson and within the wordlist itself provides irrefutable evidence that Kalloongoo was a Kaurna woman and was not from Port Lincoln as Robinson himself and a number of other sources suggest. Nor was Emue or Emma from Port Lincoln, being Kalloongoo's sister-in-law she was either Kaurna or from a neighbouring group. The historical record can be reliably corrected in this respect.

It is remarkable that we should still be turning up 'new' wordlists of Kaurna to augment known historical sources. Robinson's Kaurna wordlist remained unidentified

${ }^{51}$ Plomley, 1976, pp. 21-21. 
or mis-identified for so long because it was included with Robinson's Tasmanian materials and there was a total absence of any notations on the pages themselves which would identify the source.

Whilst most of the words recorded in Robinson's Kaurna source are well known, the wordlist does provide several additional terms that have not been elsewhere recorded and does provide solid evidence for a distinctive southern Kaurna dialect. It also provides solid evidence for Kaurna country extending down to Cape Jervis. The status of this region as Kaurna country has been questioned recently by the publication of Berndt's book $A$ World That Was which includes a map with Ramindjeri territory extending right up to Noarlunga on the southern outskirts of the city of Adelaide. ${ }^{52}$ Berndt's sources were Ngarrindjeri, interviewed this century. His map represents a postcontact reality from a Ngarrindjeri perspective and points to a movement of Ngarrindjeri people into an area that was depopulated of its original inhabitants.

Perhaps even more interesting than the words themselves are the historical events surrounding the wordlist and the movement of Kaurna people over vast distances during the pre-colonial historical period.

It is possible that other obscure historical sources on the Kaurna language may surface in the future. In the absence of speakers of the language, any attempts to reclaim and relearn the Kaurna language necessarily rely totally on these historical sources. It is remarkable just how much progress can be made by piecing together information recorded more than one and a half centuries ago.

\section{Acknowledgements}

To Philip Clarke my thanks for 'opening the door' to the literature on sealing and whaling and for access to a pre-publication copy of his paper. I also thank Julie Tree, Librarian at SSABSA, and the staff of the Mitchell Library in Sydney for their assistance in gaining access to some of Robinson's handwritten manuscripts and for facilitating permission for their reproduction here. Ian Clarke kindly gave advice regarding their interpretation. I thank Richard Barwick and Isabel McBryde for assistance in the preparation of maps appearing in this paper. Most of all, I thank Jane Simpson and Mary-Anne Gale for their many helpful comments on an earlier draft of this paper.

Rob Amery is currently completing a PhD in Linguistics at the University of Adelaide where he is researching efforts to relearn and revive Kaurna, the language of the Adelaide Plains, from nineteenth century sources. In 1997, with the support of the Kaurna people, he introduced a course in Kaurna linguistics at the University of Adelaide.

\section{References}

Amery, Rob forthcoming, 'Sally and Harry: Insights into Early Kaurna Contact History.' to appear in Aboriginal History, Monograph 5 edited by Luise Hercus \& Jane Simpson.

\footnotetext{
${ }^{52}$ Berndt's 1993: 304.
} 
Barwick, Diane E. 1985, 'This Most Resolute Lady: A Biographical Puzzle.' pp.185-239 in Barwick, D.E., Beckett, J. \& Reay, M. (eds) Metaphors of Interpretation: Essays in Honour of W.E.H. Stanner. ANU Press, Canberra.

Berndt, R.M. \& C. H. Berndt with J.E. Stanton 1993, A World That Was: The Yaraldi of the Murray River and the Lakes, South Australia. Melbourne University Press at the Miegunyah Press, Carlton.

Clark, Philip forthcoming, 'Early European Interaction with Aboriginal Hunters and Gatherers on Kangaroo Island, South Australia.' Aboriginal History, this volume.

Cumpston, J.S. 1970, Kangaroo Island 1800-1836. Roebuck Society, Canberra.

Gaimard, M. 1833, 'Vocabulaire de la langue des Habitans du Golfe Saint-Vincent.' in De M.J. Dumont D'Urville Voyage de Déciouvertes de L'Astrolabe 1826-1827-1828-1829: Philologie Publié par Le Ministére de la Marine, Paris.

Mollison, B.C. 1976, The Tasmanian Aborigines Vol.3 Part 1 Tasmanian Aboriginal Genealogies, with an Appendix on Kangaroo Island. Psychology Department, University of Tasmania.

Nunn, J. M. 1989, The Southern Land: A Social History of Kangaroo Island 1800-1890. Investigator Press, Adelaide.

Plomley, N.J.B. (ed.) 1966, Friendly Mission: The Tasmanian Journals and Papers of George Augustus Robinson 1829-1834. Tasmanian Historical Research Association.

Plomley, N.J.B. 1976, A Word-list of the Tasmanian Aboriginal Languages. The Author, Launceston.

Plomley, N.J.B. Ed. 1987, Weep in Silence: A History of the Flinders Island Aboriginal Settlement. Blubber Head Press, Hobart.

Plomley, N.J.B. \& K.A. Henley 1990, The Sealers of Bass Strait and the Cape Barren Island Community. Blubber Head Press, Hobart.

Rae Ellis, Vivienne 1981, Trucanini: Queen or Traitor? Australian Institute of Aboriginal Studies, Canberra.

Taplin, Rev. George 1879, The Folklore, Manners, Customs, and Languages of the South Australian Aborigines. E.Spiller, Acting Government Printer, Adelaide.

Teichelmann, C.G. \& C.W. Schürmann 1840, Outlines of a Grammar, Vocabulary, and Phraseology of the3 Aboriginal Language of South Australia, Spoken by the Natives in and for some distance around Adelaide, Facsimile edition 1982, Tjintu Books, Largs Bay.

Teichelmann, C.G. 1857, 'Dictionary of the Adelaide Dialect.' ms. No. 59 Bleek's Catalogue of Sir George Grey's Library dealing with Australian languages, South African Public Library.

Wiltshire, J.G. 1976, William Dutton and the Sealing and Whaling Industries. E. Davis \& Sons Pty Ltd, Portland.

Wyatt, William 1879, 'Some account of the Manners and Superstitions of the Adelaide and Encounter Bay Aboriginal Tribes with a Vocabulary of their Languages, Names of Persons and Places etc.' reprint from The Native Tribes of South Australia Adelaide, E.S. Wigg \& Son in Parkhouse (ed.) Reprints and Papers relating to the Autochthones of Australia, Parkhouse, Woodville, 1923. 